\title{
Uji Prebiotik Mangga Manalagi (Mangifera indica L. var manalagi) Terhadap Pertumbuhan Lactobacillus plantarum Secara In Vitro
}

\author{
Iit Lusif Tsania ${ }^{1}$, Irul Hidayati ${ }^{1}$, Ita Ainun Jariyah ${ }^{1}$ \\ ${ }^{1}$ Program Studi Biologi, Fakultas Sains dan Teknologi, Universitas Islam Negeri Sunan Ampel, \\ Jalan Ahmad Yani No 117, Surabaya 60237
}

Penulis untuk Korespondensi/E-mail: iitlusif@alamat.com

\begin{abstract}
Prebiotics are food ingredients that cannot be absorbed by the host and will be fermented by colonic bacteria into Short-Chain Fatty Acid. Prebiotics can come from various natural ingredients such as wheat, onions, and bananas. Prebiotic food sources can stimulate the growth of probiotic bacteria which are beneficial bacteria for the host, one of which can produce bacteriocins to fight pathogenic bacteria. Manalagi mango (Mangifera indica $\mathbf{L}$. var manalagi) is a fruit that has the potential as a source of prebiotics because it contains prebiotic food requirements, including dietary fiber and carbohydrates. The purpose of this study is to find out the ability or potential of Manalagi mengkal mango as a source of prebiotics by using a prebiotic test based on the growth of BAL is Lactobacillus plantarum in vitro. The design of this study used an experimental laboratory carried out in vitro by making carbon source media with various concentrations of mango flour, then mixed with liquid MRS, and given Lactobacillus plantarum culture which then measured the carbon source medium in the form of TPC. The highest TPC average yield was $1,7 \times 10^{10} \mathrm{CFU} / \mathrm{ml}$ is the variation in the concentration of mango flour $6.89 \%$. Based on the results of a prebiotic test with TPC mango flour manalagi mengkal showed its ability as a source of prebiotics by stimulating the growth of BAL (Lactobacillus plantarum).
\end{abstract}

Abstrak - Prebiotik merupakan bahan pangan yang tidak dapat diabsorbsi oleh host dan akan difermentasi oleh bakteri kolon menjadi asam-asam lemak rantai pendek (Short Chain Fatty Acid/SCFA). Prebiotik dapat berasal dari berbagai bahan alami seperti gandum, bawang, dan buah pisang. Sumber pangan prebiotik mampu menstimulasi pertumbuhan bakteri probiotik yang merupakan bakteri pemberi manfaat bagi inang, salah satunya dapat menghasilkan bakteriosin untuk melawan bakteri patogen. Mangga manalagi (Mangifera indica $\mathbf{L}$. var manalagi) termasuk buah yang berpotensi sebagai sumber prebiotik karena memiliki kandungan syarat bahan pangan prebiotik, termasuk serat pangan dan karbohidrat. Tujuan penelitian ini yaitu untuk mengetahui kemampuan atau potensi mangga manalagi mengkal sebagai sumber prebiotik dengan uji prebiotik berdasarkan pertumbuhan BAL yaitu Lactobacillus plantarum secara in vitro. Desain penelitian ini menggunakan eksperimental laboratory yang dilakukan secara in vitro dengan pembuatan media sumber karbon beberapa variasi konsentrasi tepung mangga, lalu dicampurkan dengan MRS cair, dan diberikan kultur Lactobacillus plantarum yang kemudian media sumber karbon tersebut dilakukan pengukuran berupa TPC. Hasil rata-rata TPC tertinggi $1,7 \times 10^{10} \mathrm{CFU} / \mathrm{ml}$ yaitu pada variasi konsentrasi tepung mangga 6,89\%. Berdasarkan hasil uji prebiotik dengan TPC tepung mangga manalagi mengkal menunjukkan kemampuannya sebagai sumber prebiotik dengan menstimulasi pertumbuhan BAL (Lactobacillus plantarum).

Keywords - Prebiotics, Manalagi mango, Lactobacillus plantarum 


\section{PENDAHULUAN}

$\mathrm{P}$ rebiotik merupakan bahan pangan yang tidak dapat dicerna dalam usus halus dan ketika sampai di usus besar akan difermentasi oleh bakteri kolon menjadi asam-asam lemak rantai pendek (Short Chain Fatty Acid/SCFA) seperti asetat, laktat, butirat, propionat, dan juga gas-gas (seperti $\mathrm{CO} 2$, metana, dan hidrogen). Asam lemak rantai pendek tersebut akan diabsorbsi dan dimetabolisme oleh tubuh [1]. Prebiotik umumnya berbentuk bahan serat pangan [2]. Selain itu, prebiotik yang paling potensial juga terdiri dari karbohidrat. Bahan makanan yang merupakan prebiotik dapat berupa sayur-sayuran, umbi-umbian, serta buah-buahan [3].

Beberapa penelitian sebelumnya mengenai sumber atau produk prebiotik banyak menggunakan bahan serat pangan dan karbohidrat tinggi. Salah satunya dari buah-buahan yaitu tepung pisang yang pada penelitian sebelumnya terbukti memiliki manfaat terhadap pertumbuhan probiotik Lactobacillus casei [3]. Terdapat pula penelitian lainnya mengenai penggunaan prebiotik ekstrak buah Rumbia (Metroxylon sago Rottb) yang hasilnya menunjukkan adanya pengaruh sumber prebiotik terhadap konsumsi ransum, pertambahan bobot akhir, dan efek positif lainnya pada ayam pedaging [4].

Mangga manalagi (Mangifera indica L. var manalagi) merupakan salah satu buah yang dapat dijadikan sebagai sumber prebiotik. Hal itu berdasarkan pada kandungan nutrisi mangga yang kaya akan syarat bahan pangan prebiotik yaitu serat tinggi $(1,6 \mathrm{~g} / 100 \mathrm{~g})$ [5], karbohidrat tinggi yaitu 68,5 gram $/ 100$ gram yang termasuk kadar pati tinggi $(65,67 \%)$ [6], serta kadar gula yang tinggi $(35,83 \%)$ [7]. Selain itu juga mengandung nutrisi lainnya seperti vitamin $\mathrm{C}$, vitamin $\mathrm{A}$, vitamin B6, lemak, protein, beta karoten, dan kalium [8]. Meskipun demikian, sejauh ini belum ada informasi atau penelitian yang mendalam mengenai potensi mangga manalagi sebagai sumber prebiotik.

Uji prebiotik dapat menggunakan BAL (Bakteri Asam Laktat), khususnya dari genus Lactobacillus dan Bifidobacterium yang merupakan flora normal. Salah satunya yang digunakan pada penelitian ini yaitu Lactobacillus plantarum yang merupakan bakteri dengan kemampuan menghambat kontaminasi dari mikroorganisme patogen serta penghasil racun karena dapat menghasilkan asam laktat dan menurunkan $\mathrm{pH}$. Serta mempunyai kemampuan untuk menghasilkan bakteriosin yang berfungsi sebagai zat antibiotik [9].

Berdasarkan paparan di atas, penelitian ini dilakukan dengan tujuan mengetahui kemampuan sumber prebiotik mangga manalagi berdasarkan uji prebiotiknya terhadap pertumbuhan Lactobacillus plantarum secara in vitro. Hasil dari penelitian ini diharapkan bisa memberikan informasi tambahan manfaat mangga manalagi dan meningkatkan penggunaan bahan alami salah satunya buah mangga manalagi sebagai sumber prebiotik.

\section{METODE}

\section{Desain, Tempat, dan Waktu}

Desain penelitian ini adalah eksperimental laboratory dan metode penelitian yang digunakan yaitu Rancangan Acak Lengkap (RAL) yang dilakukan secara in vitro dengan membuat media buatan, pada penelitian ini berupa media sumber karbon yang sesuai dengan lingkungan yang diperlukan bakteri untuk tumbuh. Secara in vitro ini bertujuan untuk melihat ketahanan Lactobacillus plantarum (BAL) pada lingkungan yang asam. Penelitian ini dilakukan di Laboratorium Mikrobiologi PGRI Adi Buana Surabaya mulai dari bulan Oktober 2020 hingga Januari 2021.

\section{Bahan dan Alat Penelitian}

Bahan yang digunakan dalam penelitian ini antara lain: buah mangga manalagi (Mangifera indica $\mathrm{L}$. var manalagi) mengkal, Inulin Powder, air dingin $\left(0^{\circ} \mathrm{C}\right)$, media agar MRS (de Mann, Rogosa, Sharpe), media MRS cair, aquades, $\mathrm{NaCl} 0,85 \%$, dan isolat bakteri Lactobacillus plantarum.

Alat yang digunakan dalam penelitian ini antara lain: cawan petri, rak tabung reaksi, tabung reaksi, LAF (Laminar Air Flow), tube, spektrofotometer, mikropipet, gelas bekker, blander, pisau, saringan mesh 80, erlenmeyer, oven, autoklaf, vortex, bunsen, jarum ose, timbangan analitik, tip, pengaduk, hotplate, colony counter, gelas ukur, spatula, alumunium foil, karet, kertas, plastik, kapas, dan baki.

\section{Tahapan Penelitian}

\section{Pembuatan Tepung Mangga Manalagi}

Mangga yang digunakan disiapkan yaitu dipilih dari varietas manalagi (Mangifera indica L. var manalagi) yang mengkal. Selanjutnya pencucian, pengupasan, pengirisan kurang lebih $22 \mathrm{~mm}$, dan ditimbang sebanyak 500 gram. Kemudian diberi 
perlakuan perendaman pada air dingin $0^{\circ} \mathrm{C}$ selama 10 menit, selanjutnya pengeringan dengan oven kurang lebih 3 hari pada suhu $45^{\circ} \mathrm{C}-50^{\circ} \mathrm{C}$. Setelah kering, dilakukan penepungan menggunakan blender dan diayak menggunakan ayakan 80 mesh [10].

\section{Peremajaan Bakteri}

Proses pertama yaitu pembuatan media peremajaan dengan cara menimbang media MRS cair sebanyak 2,6 gram untuk dilarutkan dalam $50 \mathrm{ml}$ aquades. Dilakukan pemanasan diatas hotplate dan pengadukan sampai tercampur rata, kemudian mulut erlemeyer ditutup. Lalu disterilisasi di dalam autoklaf dengan suhu $121^{\circ} \mathrm{C}$ dan tekanan 1 atm selama 15 menit.

Langkah berikutnya setelah disterilisasi yaitu dilakukan pembuatan media secara aseptis di dalam LAF dengan cara media MRS cair dituang ke dalam 5 tabung reaksi masing-masing sebanyak $10 \mathrm{ml}$ dan disimpan dalam inkubator. Selanjutnya kultur murni bakteri Lactobacillus plantarum diinokulasi pada media MRS cair tersebut dengan cara pengambilan biakan secara aseptis. Kemudian hasil inokulasi diinkubasi pada suhu $37^{\circ} \mathrm{C}$ selama kurang lebih 24 jam sampai terlihat adanya pertumbuhan [11].

\section{Uji Prebiotik}

Uji prebiotik pada penelitian ini dilakukan dengan mengamati jumlah pertumbuhan bakteri Lactobacillus plantarum pada tepung mangga manalagi mengkal. Langkah awal yaitu pembuatan media sumber karbon dengan variasi konsentrasi $0 \%$ (kontrol negatif); 2,87\% ; 5,59\% ; 6,89\% ; dan $6,89 \%$ (kontrol positif). Pertama menyiapkan erlenmeyer yang telah berisi media MRS cair sebanyak 0,702 gram. Kemudian menimbang tepung mangga $0 ; 0,4 ; 0,8 ; 1$; dan 1 gram kontrol positif, masing-masing dimasukkan dalam erlenmeyer dan ditambahkan aquades hingga 13,5 ml. Perlakuan tersebut dilakukan sebanyak 5 kali pengulangan pada masing-masing konsentrasi, lalu disimpan dalam inkubator.

Media sumber karbon (tepung mangga) masingmasing sebanyak 13,5 ml tersebut dimasukkan ke dalam tabung reaksi. Kemudian kultur bakteri Lactobacillus plantarum dimasukkan masingmasing sebanyak $1,5 \mathrm{ml}$ (ekuivalen=OD 2.575) ke dalam tabung reaksi tersebut. Setelah itu diinkubasi pada suhu $37^{\circ} \mathrm{C}$ selama $1 \times 24$ jam. Kemudian jumlah pertumbuhan bakteri Lactobacillus plantarum pada tepung mangga manalagi mengkal dilakukan pengukuran dengan metode TPC.

\section{TPC (Total Plate Count)}

Pertama menimbang MRS agar sebanyak 31 gram untuk dilarutkan dalam $500 \mathrm{ml}$ aquades pada erlenmeyer. Dilakukan pemanasan diatas hotplate dan pengadukan, kemudian mulut erlemeyer ditutup dan disterilisasi dalam autoklaf. Setelah disterilisasi dilakukan pembuatan media pada cawan petri secara aseptis [12].

Proses selanjutnya yaitu pengenceran, penelitian ini menggunakan pengenceran dari $\left(10^{-1}\right)$ sampai pengenceran $\left(10^{-7}\right)$ yang dilakukan dengan cara 1 ml sampel media sumber karbon dipindahkan ke dalam tabung reaksi yang sudah berisi $9 \mathrm{ml} \mathrm{NaCl}+$ aquades untuk mendapatkan pengenceran $\left(10^{-2}\right)$. Kemudian hal tersebut diulangi sampai mendapatkan pengenceran $\left(10^{-7}\right)$.

TPC dilakukan dengan 1 seri pengenceran $\left(10^{-7}\right)$ dari setiap ulangan pada masing-masing konsentrasi. Sehingga setiap konsentrasi menghasilkan 5 isolasi bakteri pada cawan petri pula. Teknik isolasi mikroba dilakukan dengan metode stread plate yaitu dengan cara $0,1 \mathrm{ml}$ suspensi atau kultur bakteri dari pengenceran $\left(10^{-7}\right)$ dimasukkan dalam cawan petri berisi media MRS agar (media untuk perhitungan TPC) yang sudah dibuat sebelumnya, kemudian ditutup rapat cawan petri dan diinkubasi selama 48 jam pada suhu $37^{\circ} \mathrm{C}$. Proses selanjutnya dilakukan perhitungan koloni bakteri Lactobacillus plantarum pada media agar atau jumlah TPC dengan colony counter.

\section{Pengolahan dan Analisis data}

Analisis hasil uji prebiotik tepung mangga manalagi terhadap pertumbuhan Lactobacillus plantarum berupa data hasil TPC dilakukan secara deskriptif yang disajikan dalam bentuk tabel dan grafik. Selain itu juga dilakukan analisis dengan uji One Way Anova untuk melihat ada tidaknya pengaruh variasi konsentrasi. Uji One Way Anova ini dilakukan setelah data melewati uji asumsi berupa uji normalitas (Shaphiro-Wilk) dan uji homogenitas (Levene's test).

\section{HASIL DAN PEMBAHASAN}

Aktivitas prebiotik mangga manalagi (Mangifera indica $\mathrm{L}$. var manalagi) mengkal pada penelitian ini dapat dilihat dari adanya pertumbuhan bakteri Lactobacillus plantarum yang menggunakan substrat tepung mangga manalagi mengkal sebagai sumber karbon pada media pertumbuhan bakteri. 
Adanya pertumbuhan bakteri berdasarkan pengamatan uji prebiotik ini dilakukan dengan mengukur pertumbuhan Lactobacillus plantarum berupa peningkatan hasil TPC.

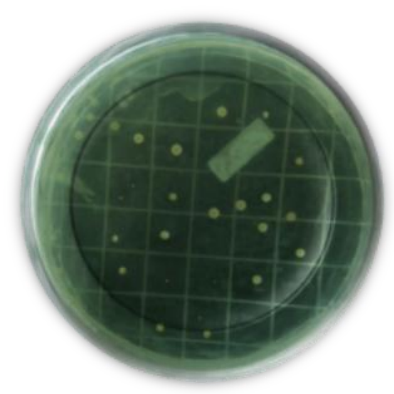

Gambar 1 Hasil TPC koloni bakteri Lactobacillus plantarum

Berdasarkah hasil penelitian menunjukkan terdapat pertumbuhan bakteri Lactobacillus plantarum dan terlihat morfologi isolat bakteri yaitu berbentuk bulat dan berwarna putih mengkilat. Hal ini sejalan dengan hasil penelitian Ulum (2018) yaitu isolasi pengujian BAL dari buah mangga manalagi yang mampu tumbuh pada media MRS agar dengan karakter morfologi koloni teramati 5 isolat bakteri. Sampel isolat BAL tersebut berdasarkan pengamatan makroskopis memiliki ciri-ciri berwarna putih susu, bulat, tepian licin, dan elevasi cembung. Lalu berdasarkan pengamatan mikroskopisnya menunjukkan hasil bahwa isolat tersebut adalah bakteri BAL genus Lactobicillus [13].

Hasil perhitungan rata-rata total BAL menggunakan metode TPC ditunjukkan pada Tabel 1 sebagai berikut:

Tabel 1. Hasil pertumbuhan koloni Lactobacillus plantarum pada berbagai konsentrasi tepung mangga menggunakan metode TPC

\begin{tabular}{cc}
\hline \multicolumn{2}{c}{$\begin{array}{c}\text { Jumlah Koloni Pada } \mathbf{1 0}^{\mathbf{- 7}} \text { (Standar Plate Count) } \\
\text { CFUl }\end{array}$} \\
\hline Konsentrasi & Rata-Rata \\
\hline $0 \%$ (kontrol negatif) & $5,6 \times 10^{9}$ \\
$6,89 \%$ (kontrol positif) & $7,5 \times 10^{9}$ \\
$2,87 \%$ & $8,1 \times 10^{9}$ \\
$5,59 \%$ & $1,2 \times 10^{10}$ \\
$6,89 \%$ & $1,7 \times 10^{10}$ \\
\hline
\end{tabular}

Berdasarkan hasil perhitungan koloni bakteri pada Tabel 1 tersebut diketahui bahwa semua sampel memenuhi syarat perhitungan TPC. Serta menunjukkan bahwa hasil perhitungan meningkat sejalan dengan bertambahnya konsentrasi dengan rata-rata tertinggi terdapat pada tepung mangga konsentrasi $6,89 \%$ yaitu $1,7 \times 10^{10} \mathrm{CFU} / \mathrm{ml}$. Hasil tersebut juga sejalan dengan hasil penelitian oleh Widanarni et all yang menyatakan bahwa tingginya total bakteri pada perlakuan prebiotik dikarenakan sumber prebiotik yang diberikan mampu menstimulasi pertumbuhan bakteri potensial yang menguntungkan dengan memberikan substrat berupa prebiotik yang dapat dicerna oleh bakteri sehingga populasinya meningkat dan dapat melawan bakteri patogen [14].

Data hasil TPC tersebut selanjutnya diuji statistik One Way Anova. Pertama dilakukan uji asumsi yaitu uji normalitas menggunakan uji Shaphiro-Wilk yang hasilnya menunjukkan nilai signifikan $0,380>\mathrm{p}$ $(0,05)$ yang berarti data berdistribusi normal serta dilakukan uji homogenitas dengan uji Levene's test yang didapatkan nilai $0,424>\mathrm{p}(0,05)$, hal ini menunjukkan bahwa varians data homogen. Kemudian dilanjutkan uji One Way Anova dengan hasil sebagai berikut:

Tabel 2. Hasil uji One Way Anova parameter hasil TPC

\begin{tabular}{lccccc}
\hline & $\begin{array}{c}\text { Sum of } \\
\text { Squares }\end{array}$ & Df & $\begin{array}{c}\text { Mean } \\
\text { Square }\end{array}$ & F & Sig. \\
\hline $\begin{array}{l}\text { Between } \\
\text { Groups }\end{array}$ & $4.998 \mathrm{E} 20$ & 4 & $1.249 \mathrm{E} 20$ & 20.563 & .000 \\
$\begin{array}{l}\text { Within } \\
\text { Groups }\end{array}$ & $1.215 \mathrm{E} 20$ & 20 & $6.076 \mathrm{E} 18$ & & \\
Total & $6.213 \mathrm{E} 20$ & 24 & & & \\
\hline
\end{tabular}

Hasil uji hipotesis One Way Anova pada Tabel 2 menunjukkan $\mathrm{p}$ value ( signifikansi) $0,000<\mathrm{p}(0,05)$ sehingga $\mathrm{H} 0$ ditolak dan $\mathrm{H} 1$ diterima yang berarti terdapat perbedaan antar perlakuan. Berdasarkan hasil dari uji statistik One Way Anova tersebut juga dapat diketahui bahwa pemberian variasi konsentrasi tepung mangga manalagi mengkal sebagai sumber prebiotik berpengaruh terhadap pertumbuhan bakteri Lactobacillus plantarum.

Berdasarkan hasil TPC dilihat pada Tabel 1 jumlah pertumbuhan Lactobacillus plantarum pada jam ke48 tersebut mengalami peningkatan yang sejalan dengan peningkatan konsentrasi sumber karbon (tepung mangga manalagi mengkal) pada media pertumbuhan bakteri yang berarti hal ini berkaitan dengan meningkatnya jumlah sumber prebiotik yang digunakan.

Tepung mangga manalagi (Mangifera indica L. var manalagi) dapat menjadi sumber karbon pada pertumbuhan Lactobacillus plantarum, sesuai 
dengan pernyataan Reddy (2015) bahwa mangga manalagi memiliki konsentrasi tinggi gula (16-18\% $\mathrm{b} / \mathrm{v}$ ) dan asam. Konsentrasi gula yang tinggi pada mangga manalagi tersebut dikarenakan adanya produksi asam laktat yang mampu membantu pertumbuhan Bakteri Asam Laktat pada mangga manalagi misalnya jenis Lactobacillus plantarum dan Lactobacillus delbruekii [15].

Mangga manalagi yang masih mengkal memiliki kadar gula sebesar $(35,83 \%)$ [7]. Selain itu kemampuan tepung mangga manalagi mengkal sebagai sumber prebiotik juga karena mengandung karbohidrat tinggi yaitu 68,5 gram/100 gram yang termasuk kadar pati tinggi $(65,67 \%)$ [6]. Hal ini sesuai dengan pendapat Huebner et al. (2007) bahwa karbohidrat memiliki aktivitas prebiotik positif apabila dimetabolisme oleh Lactobacillus dan secara selektif dimetabolisme pula oleh probiotik tetapi tidak oleh bakteri yang lain [16]. Selain itu, proses fermentasi yang merupakan pemecahan karbohidrat menjadi bentuk monosakarida dan dari monosakarida dengan bantuan enzim emilase yang dihasilkan oleh Lactobacillus sp. akan diubah menjadi asam laktat sehingga membuat lingkungan asam dan organisme patogen tidak mampu hidup [17].

Hasil ini berkaitan pula dengan kandungan serat pangan yang tinggi yaitu 1,6 g/100 g pada mangga manalagi yang di mana serat pangan termasuk syarat bahan pangan prebiotik [5]. Serat larut dalam jalur gastrointestinal akan difermentasi dalam caecum oleh bakteri anaerob untuk menghasilkan asam lemak rantai pendek atau Short Chain Fatty Acid (SCFA) yang secara cepat akan diserap oleh penghuni kolon sebagai sumber energi untuk perkembangbiakan [18].

Media kontrol negatif yang tidak diberikan tepung mangga pada penelitian ini didapatkan hasil rata-rata 5,6 $\times 10^{9} \mathrm{CFU} / \mathrm{ml}$ sedangkan hasil jumlah Lactobacillus plantarum tertinggi rata-rata $1,7 \mathrm{x}$ $10^{10} \mathrm{CFU} / \mathrm{ml}$ terdapat pada media yang diberikan tepung mangga dengan konsentrasi paling tinggi yaitu $6,89 \%$. Perlakuan kontrol positif berupa pemberian prebiotik komersial (inulin powder) dengan konsentrasi yang sama yaitu $6,89 \%$ menunjukkan hasil rata-rata $7,5 \times 10^{9} \mathrm{CFU} / \mathrm{ml}$. Hasilnya bahkan lebih rendah dibandingkan dengan hasil perlakuan pemberian tepung mangga manalagi mengkal $6,89 \%$ dengan perbedaan yang cukup signifikan. Hal ini menunjukkan tepung mangga manalagi mampu menjadi media sumber karbon yang dapat mendorong pertumbuhan bakteri probiotik serta menunjukkan bahwa tepung mangga manalagi mengkal memiliki kemampuan sebagai sumber prebiotik yang bisa dibandingkan dengan sumber prebiotik komersial.

Penelitian sebelumnya oleh Hidayat et al. (2013) mengenai total BAL pada media drink yoghurt dengan penambahan ekstrak buah mangga menunjukkan hasil rata-rata $T^{0}$ ke $T^{1}$ terjadi peningkatan total BAL dari 7,57462 ke 7,97472 log. Hal tersebut dikarenakan penambahan ekstrak buah mangga dapat memberikan nutrisi berlebih untuk pertumbuhan BAL. Serta berdasarkan hasil uji profil gula didapatkan kandungan glukosa dalam drink yoghurt tanpa penambahan ekstrak buah mangga sebesar $0,729 \%$, sedangkan dengan penambahan ekstrak buah mangga didapatkan $0,5410 \%$ yang berarti menunjukkan bahwa BAL dalam drink yoghurt dengan adanya penambahan ekstrak buah mangga dapat memanfaatkan glukosa dalam buah mangga untuk meningkatkan pertumbuhannya [19].

Berdasarkan hasil penelitian ini aktivitas prebiotik menunjukkan kemampuan substrat berupa sumber karbon tepung mangga ini mampu meningkatkan pertumbuhan bakteri Lactobacillus plantarum. Optimalnya pertumbuhannya pada suatu konsentrasi menunjukkan bahwa pada konsentrasi tersebut tepung mangga manalagi mengkal optimal sebagai sumber prebiotik yang pada penelitian ini yaitu konsentrasi tepung mangga manalagi mengkal 6,89\%, pada konsentrasi tersebut menghasilkan pertumbuhan bakteri Lactobacillus plantarum paling optimal dibandingkan dengan perlakuan yang lain yaitu $0 \%$ (kontrol negatif); 2,87\%; 5,59\%; $6,89 \%$ dan $6,89 \%$ prebiotik komersial (kontrol positif).

\section{KESIMPULAN}

Mangga manalagi (Mangifera indica L. var manalagi) mengkal yang kaya syarat bahan pangan prebiotik memiliki kemampuan sebagai sumber prebiotik. Berdasarkan uji prebiotiknya terhadap pertumbuhan Lactobacillus plantarum secara in vitro menunjukkan adanya peningkatan jumlah pertumbuhan Lactobacillus plantarum yang meningkat sejalan dengan meningkatnya konsentrasi sumber karbon (tepung mangga manalagi mengkal) yang diberikan. Hasil TPC paling tinggi atau paling optimal dalam pertumbuhan Lactobacillus plantarum adalah konsentrasi yang paling tinggi $6,89 \%$ yaitu $1,7 \mathrm{x}$ $10^{10} \mathrm{CFU} / \mathrm{ml}$. 


\section{UCAPAN TERIMA KASIH}

Penulis mengucapkan terima kasih kepada bu Irul Hidayati dan bu Ita Ainun Jariyah selaku dosen pembimbing yang telah banyak memberikan saran dan masukan hingga penelitian selesai, serta kepada seluruh staff Laboratorium UNIPA yang telah banyak membantu selama proses penelitian.

\section{REFERENSI}

[1] Ngatirah, "Probiotik, Prebiotik dan Sinbiotik," Jurnal Teknologi dan Enjiniring Pertanian, vol. 4, no. 2, 2009.

[2] Y. Wang, "Prebiotics: Present and Future in Food Science and Technology," Food Research International, vol. 42, no. 1, pp. 812, 2009.

[3] R. Hardisari and N. Amaliawati, "Manfaat Prebiotik Tepung Pisang Kepok (Musa paradisiaca formatypica) terhadap Pertumbuhan Probiotik Lactobacillus casei secara In Vitro," Jurnal Teknologi Laboratorium, vol. 5, no. 2, pp. 64-67, 2016.

[4] M. Daud, W. G. Piliang, k. G. Wiryawan and A. Setiyono, "Penggunaan Prebiotik Oligosakarida Ekstrak Tepung Buah Rumbia (Metroxylon sago Rottb.) dalam Ransum terhadap Performan Ayam Pedaging," Jurnal Agripet, vol. 9, no. 2, 2009.

[5] M. Lauricella, S. Emanuele, G. Calvaruso, M. Giuliano and A. D'Anneo, "Multifaceted Health Benefits of Mangifera indica L. (Mango): The Inestimable Value of Orchards Recently Planted in Sicilian Rural Areas," Nutrients, vol. 9, no. 5, 2017.

[6] Ifmaily, "Penetapan Kadar Pati Pada Buah Mangga Muda ( Mangifera Indica L ) Menggunakan Metode Luff Schoorl," Jurnal Katalisator, vol. 3, no. 2, 2018.

[7] N. Kartikorini, "Analisa Kadar Gula (Sukrosa) Buah Mangga Berdasarkan Varietasnya," Surabaya Repository, Surabaya, 2016.

[8] M. H. Leghari, S. A. Sheikh, M. B. Kumbhar and A. F. Baloch, "Mineral Content in Dehydrated Mango Powder," Journal of Basic \& Applied Sciences, vol. 9, no. 4, pp. 21-25, 2013.

[9] D. Maryana, "Pengaruh Penambahan Sukrosa Terhadap Jumlah Bakteri dan Keasaman Whey Fermentasi dengan Menggunakan
Kombinasi Lactobacillus Plantarum dan Lactobacillus achidopilus," Universitas Hasanuddin, Makassar, 2014.

[10] O. Paramita, "Kajian Proses Pembuatan Tepung Buah Mangga (Mangivera Indica L) Varietas Arumanis Dengan Suhu Perendaman yang Berbeda," Jurnal Bahan Alam Terbarukan, vol. 1, no. 1, 2012.

[11] M. A. Trinanda, "Studi Aktivitas Bakteri Asam Laktat (L. Plantarum dan L. Fermentum) Terhadap Kadar Protein Melalui Penambahan Tepung Kedelai pada Bubur Instan Terfermentasi," Universitas Negeri Yogyakarta, Yogyakarta, 2019.

[12] A. Meiliawati, "Pengaruh Penambahan Garam 5\% dan 7,5\% Terhadap Potensi Probiotik Bakteri Asam Laktat Hasil Fermentasi Acar Kubis Putih (Brassica oleracea) Asal Getasan, Kopeng," Universitas Katolik Soegijapranata, Semarang, 2017.

[13] B. Ulum, "Isolasi dan Karakterisasi Bakteri Asam Laktat dari Buah Mangga (Mangifera Indica L.) Sebagai Antibakteri Escherichia coliDAN Staphylococcus aures," Universitas Islam Negeri Maulana Malik Ibrahim, Malang, 2018.

[14] Widanarni, J. I. Noermala and Sukenda, "Prebiotic, probiotic, and synbiotic to control Vibrio harveyi and IMNV co-infection in Litopenaeus vannamei," Jurnal Akuakultur Indonesia, vol. 13, no. 1, 2014.

[15] L. V. Reddy and a. Y.-J. W. Ju-Hee Min, "Production of Probiotic Mango Juice by Fermentation of Lactic Acid Bacteria," Microbiology and Biotechnology Letters, vol. 43, no. 2, 2015.

[16] J Huebner, R L Wehling, R W Hutkins, "Functional Activity of Commercial Prebiotics," Food Science and Technology, vol. 17, no. 7, 2007.

[17] M. A. K. Budiyanto, Mikrobiologi Terapan, Malang: Universitas Muhammadiyah, 2002.

[18] T. Haryati, "Probiotics and Prebiotics as Feed Additive For Nonruminants," Wartazoa, vol. 21, no. 3, 2011.

[19] I. R. Hidayat, K. Kusrahayu and S. Mulyani, "Total Bakteri Asam Laktat Nilai pH dan Sifat Organoleptik Drink Yoghurt dari susu Sapi yang Diperkaya dengan Ekstrak Buah Mangga," Animal Agriculture Journal, vol. 2, no. 1, 2013. 
